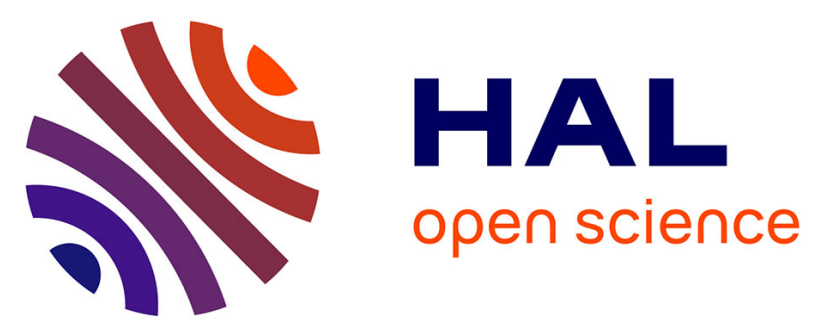

\title{
Cheese-flavored expanded snacks with low lipid content: Oil effects on the in vitro release of butyric acid and on the duration of the dominant sensations of the products
}

Michele Eliza Cortazzo Menis-Henrique, Natália Soares Janzantti, Isabelle Andriot, Etienne Semon, Olivier Berdeaux, Pascal Schlich, Ana Carolina

Conti-Silva

\section{To cite this version:}

Michele Eliza Cortazzo Menis-Henrique, Natália Soares Janzantti, Isabelle Andriot, Etienne Semon, Olivier Berdeaux, et al.. Cheese-flavored expanded snacks with low lipid content: Oil effects on the in vitro release of butyric acid and on the duration of the dominant sensations of the products. LWT

- Food Science and Technology, 2019, 105, pp.30-36. 10.1016/j.lwt.2019.01.052 . hal-02619762

\section{HAL Id: hal-02619762 \\ https://hal.inrae.fr/hal-02619762}

Submitted on 25 May 2020

HAL is a multi-disciplinary open access archive for the deposit and dissemination of scientific research documents, whether they are published or not. The documents may come from teaching and research institutions in France or abroad, or from public or private research centers.
L'archive ouverte pluridisciplinaire HAL, est destinée au dépôt et à la diffusion de documents scientifiques de niveau recherche, publiés ou non, émanant des établissements d'enseignement et de recherche français ou étrangers, des laboratoires publics ou privés. 
Cheese-flavored expanded snacks with low lipid content: Oil effects on the in vitro release of butyric acid and on the duration of the dominant sensations of the products

Michele Eliza Cortazzo Menis-Henrique, Natália Soares Janzantti, Isabelle Andriot, Etienne Sémon, Olivier Berdeaux, Pascal Schlich, Ana Carolina Conti-Silva

\author{
PII: \\ S0023-6438(19)30063-5 \\ DOI: $\quad$ https://doi.org/10.1016/j.lwt.2019.01.052 \\ Reference: YFSTL 7794 \\ To appear in: $\quad$ LWT - Food Science and Technology
}

Received Date: 20 September 2018

Revised Date: 25 January 2019

Accepted Date: 27 January 2019

Please cite this article as: Menis-Henrique, M.E.C., Janzantti, Natá.Soares., Andriot, I., Sémon, E., Berdeaux, O., Schlich, P., Conti-Silva, A.C., Cheese-flavored expanded snacks with low lipid content: Oil effects on the in vitro release of butyric acid and on the duration of the dominant sensations of the products, LWT - Food Science and Technology (2019), doi: https://doi.org/10.1016/j.lwt.2019.01.052.

This is a PDF file of an unedited manuscript that has been accepted for publication. As a service to our customers we are providing this early version of the manuscript. The manuscript will undergo copyediting, typesetting, and review of the resulting proof before it is published in its final form. Please note that during the production process errors may be discovered which could affect the content, and all legal disclaimers that apply to the journal pertain. 
1 Cheese-flavored expanded snacks with low lipid content: oil effects on the in vitro release

2 of butyric acid and on the duration of the dominant sensations of the products

3 Michele Eliza Cortazzo Menis-Henrique ${ }^{1 *}$, Natália Soares Janzantti ${ }^{1}$, Isabelle Andriot ${ }^{2}$,

4 Etienne Sémon ${ }^{2}$, Olivier Berdeaux ${ }^{2}$, Pascal Schlich $^{2}$, Ana Carolina Conti-Silva $^{1}$

$5 \quad{ }^{1}$ São Paulo State University (Unesp), Institute of Biosciences, Humanities and Exact Sciences

6 (Ibilce), Department of Food Engineering and Technology, Rua Cristóvão Colombo, 2265,

7 CEP 15054-000, São José do Rio Preto, SP, Brazil.

8 '2INRA, UMR 1324 Centre des Sciences du Goût et de l'Alimentation (CSGA), 17 Rue de

9 Sully, 21065, Dijon, France.

10 * Corresponding author

11 M. E. C. Menis-Henrique

12 Telephone: +551732212565

13 E-mail address: micheleecmenis@gmail.com 


\section{Abstract}

15 With the aim of producing snacks with reduced lipid content, the effect of lipids on the in

16 vitro release of butyric acid and on the duration of the dominant sensations of cheese-flavored

17 expanded snacks were investigated. For that, snacks were obtained through pre-extrusion

18 addition of aroma precursors of cheese to corn grits (butyric acid and cysteine) and sprinkled

19 with sunflower oil in different proportions $(6,12,18$ and $24 \mathrm{~g} / 100 \mathrm{~g})$. The snack sprinkled

20 with $6 \mathrm{~g} / 100 \mathrm{~g}$ of sunflower oil showed higher release of butyric acid, compared to the other

21 snacks with oil, when a chewing simulator was employed (simulation of aroma perception),

22 and practically the same release in relation to the other snacks when the dynamic headspace of

23 products was obtained (i.e. simulation of odor perception). All snacks with sunflower oil were

24 described by the duration of salty taste, crunchy/crisp, cheese flavor, umami taste and oil

25 flavor, indicating that the low use of sunflower oil $(6 \mathrm{~g} / 100 \mathrm{~g})$ did not alter or prejudice the

26 dominant sensations of the snacks. Therefore, the production of snacks with low addition of

27 lipids is feasible, improving the nutritive value of these products that are so criticized because

28 of the high lipid content.

30 Keywords: aroma precursors, thermoplastic extrusion, chewing simulator, Temporal

31 Dominance of Sensations (TDS). 


\section{Introduction}

Expanded snacks are widely consumed around the world and are obtained through a thermoplastic extrusion process. After extrusion, the snacks are flavored in the conventional way by food industries (post-extrusion flavoring), when a mixture of a lipid vehicle (oil or hydrogenated vegetal fat), salt and additives (commercial aroma and flavor enhancers) is sprinkled on the snacks (Maskan \& Altan, 2012). This flavoring process increases the lipid and salt content in the snacks, as well the caloric value, reasons why these products are much criticized. Corn snacks marketed in Brazil presents total lipid content from 11 to $30 \mathrm{~g} / 100 \mathrm{~g}$ and energy values from 408 to $500 \mathrm{kcal}$ per $100 \mathrm{~g}$ product (values observed at labels). These values are similar to those presented in the Brazilian Table of Food Composition (Tabela Brasileira de Composição de Alimentos, 2018), in which commercial corn snacks have a lipid content from 15 to $35 \mathrm{~g} / 100 \mathrm{~g}$ and an energy from 448 to $555 \mathrm{kcal}$ per $100 \mathrm{~g}$ product. Healthier versions of this product may be obtained using pre-extrusion flavoring, by adding many types of flavoring agents to the raw material to be extruded (Bhandari, D'Arcy, \& Young, 2001; Yuliani, Torley, D’Arcy, Nicholson, \& Bhandari, 2006; Menis, Milani, Jordano, Boscolo, \& Conti-Silva, 2013). With this technique of flavoring, the use of a lipid vehicle can be minimized. However, the suppression of lipids may compromise the sensory quality of the products because of the important contributions of lipids to the flavor of foods.

The flavor of a food is the manifestation of interactions between taste, aroma and oral sensations, since taste and oral sensations are associated with non-volatile compounds, while aroma is associated with volatile compounds. The release of volatile compounds from foods during chewing depends on their interaction with the food matrix and both static and dynamic factors are involved in this release. The static equilibrium of the volatile compounds is distributed in the food between the solid matrix, the hydrophilic liquid phase, the liquid lipophilic phase and the gas phase. This distribution is controlled by the partition coefficient 
57 of the molecules of the volatile compounds, which affects their volatility. In addition, the

58 mass transfer (a dynamic factor) depends on the viscosity of the food matrix and its interfaces,

59 in which more viscous products release the volatile compounds more slowly (Gaonkar \&

60 McPherson, 2006; Reineccius, 2006). In this way, lipids act as transporters and modulators of

61 volatile compounds in food. Even in products with reduced lipid content, the release of

62 volatile compounds can also be altered, negatively affecting the perception of the odor and

63 aroma of foods and, consequently, the flavor (Taylor \& Linforth, 2010; Voilley \& Etiévant,

64 2006). Moreover, lipids have been investigated as the $6^{\text {th }}$ basic taste (Dramane, Akpona,

65 Besnard, \& Khan, 2014), given their importance to the flavor of food. The reduction in or

66 even elimination of lipid content in food is still a challenge.

67 Therefore, with the aim of producing snacks with better nutritive value through

68 reduction of lipids for flavoring, using the pre-extrusion flavoring method, butyric acid and

69 cysteine were added as aroma precursors of cheese to corn grits (Martínez-Cuesta, Peláez, \&

70 Requena, 2013) and sunflower oil was sprinkled in different quantities onto the snacks.

71 Butyric acid is a volatile compound that contributes to cheese odors, and considering that

72 lipids influences odor, aroma and flavor of foods, the in vitro release of butyric acid was

73 monitored in this work because of the different quantities of oil sprinkled onto the snacks.

74 Moreover, techniques that allow a dynamic sensory evaluation of foods, such as the Temporal Dominance of Sensations (TDS), provide complete information about how dominant sensations vary during the consumption (Lawless \& Heymann, 2010; Pineau et al., 2009). Thus, TDS is an interesting technique to be applied to snacks, both for providing information about dominant sensory sensations, which may be related to lipid content, and also because studies about the application of TDS to snacks were not found in the literature.

\section{Material and Methods}




\section{$81 \quad 2.1$ Material}

Corn grits (Capela do Alto, Brasil), salt (Cisne, Cabo Frio, Brasil), flavor enhancer monosodium glutamate (Ajinomoto, Limeira, Brasil) and sunflower oil (Liza, Mairinque, Brasil) were used to produce the expanded snacks. Food-grade butyric acid (Sigma-Aldrich, Milwaukee, USA, code W222119, purity $>99 \mathrm{~g} / 100 \mathrm{~g}$ ) and amino acid cysteine (L-cysteine HCL anhydrous, Infinity Pharma, Campinas, Brazil, purity $>98.5 \mathrm{~g} / 100 \mathrm{~g}$ ) were used as aroma precursors of cheese on the expanded snacks.

The reagents $\mathrm{NaHCO}_{3}, \mathrm{~K}_{2} \mathrm{HPO}_{4} \cdot 3 \mathrm{H}_{2} \mathrm{O}, \mathrm{NaCl}, \mathrm{KCl}, \mathrm{CaCl}_{2} \cdot 2 \mathrm{H}_{2} \mathrm{O}, \mathrm{NaN}_{3}$, bovine mucin (reference Sigma: M3895), and porcine alpha-amylase (reference Sigma: A4268), all from Sigma-Aldrich (Milwaukee, USA), were used for production of artificial saliva.

\subsection{Preparation of corn grits and extrusion processing}

Butyric acid and cysteine (addition of $0.4 \mathrm{~g} / 100 \mathrm{~g}$ and $0.2 \mathrm{~g} / 100 \mathrm{~g}$, respectively) were added to corn grits (previously an adjusted to $15 \mathrm{~g} / 100 \mathrm{~g}$ moisture content in dry basis). The addition of butyric acid (liquid compound) was performed in volume based on the density, i.e., the mass of butyric acid to be added to the corn grits was converted to volume using its density. The addition of cysteine (powder) was done in mass. The mixture of corn grits with butyric acid and cysteine was performed through manual agitation of the bags, which were sealed and kept under refrigeration for $24 \mathrm{~h}$, for better distribution of butyric acid in the corn grits. Then, the mixture was kept at room temperature for $2 \mathrm{~h}$ before extrusion.

Corn grits with the aroma precursors added was extruded in an RXPQ Labor 24 single screw extruder (INBRAMAQ, Ribeirão Preto, Brazil) with five independent heating zones.

Extrusion conditions were: helicoidally grooved barrel; screw with a compression ratio of 2.3:1 and length-to-diameter ratio of 15.5:1; pre-die extruder with holes of $3.01 \mathrm{~mm}$; extruder die with a diameter of $2.93 \mathrm{~mm}$ (round hole); feed rate of $265 \mathrm{~g} / \mathrm{min}$; screw speed at $192 \mathrm{rpm}$; 
105 temperatures in the zones 1 to 5 : off (approximately $25^{\circ} \mathrm{C}$ ), $70{ }^{\circ} \mathrm{C}, 90^{\circ} \mathrm{C}, 120^{\circ} \mathrm{C}$ and $120^{\circ} \mathrm{C}$, 106 respectively.

After extrusion, salt $(1.4 \mathrm{~g} / 100 \mathrm{~g})$ and monosodium glutamate $(0.6 \mathrm{~g} / 100 \mathrm{~g})$ were added to the snacks and then sunflower oil was sprinkled on the snacks in the proportions of 6,12 , 18 , or $24 \mathrm{~g} / 100 \mathrm{~g}$. Two control snacks were produced under the same extrusion conditions: 1) a snack with salt and monosodium glutamate, but without aroma precursors and sunflower oil

111 (control evaluated only through TDS), and 2) snack with aroma precursors, salt and 112 monosodium glutamate, but without sunflower oil $(0 \mathrm{~g} / 100 \mathrm{~g})$. The amounts of salt, 113 monosodium glutamate and sunflower oil correspond to the addition of these ingredients in $114100 \mathrm{~g}$ of snack.

\subsection{Evaluation of butyric acid in vitro release from the expanded snacks}

The butyric acid was added to corn grits as an aroma precursor of cheese in the expanded snacks, being a volatile compound that has an important contribution to the odor/aroma of cheese (Martínez-Cuesta, Peláez, \& Requena, 2013). The in vitro release of butyric acid was monitored using a Proton Transfer Reaction Time-of-Flight Mass Spectrometer (PTR-ToF-MS) connected to two different devices: chewing simulator and valve system.

In the chewing simulator, the snacks were mixed with artificial saliva to reproduce mastication. In this way, this system may represent the release of butyric acid inside the mouth, i.e., retronasal olfaction. The valve system allows the evaluation of the dynamic headspace from the snack, representing orthonasal olfaction. Therefore, considering the operation of the two devices, and for better understanding of our results, the two evaluations

127 of in vitro release were called via aroma (chewing simulator) and via odor (valve system), respectively. 
131 composed of an active cell, where the mastication process is performed, an electronic control

132 box and a computer to monitor and adjust each parameter (Salles et al., 2006; Salles, Tarrega, Mielle, Maratray, \& Gorria, 2007). The active cell is formed by a mobile lower jaw, a mobile tongue, and a fixed upper jaw. The lower and upper jaws are ring-shaped cylinders composed only of molar teeth made of polyether ether ketone (PEEK), and the tongue is also made of PEEK, in the shape of a cylinder with a $4.5 \mathrm{~cm}$ diameter (Salles et al., 2007).

Artificial saliva used during the chewing simulation was prepared according to the protocol used by the Centre des sciences du goût et de l'alimentation at the Institut National de la Recherche Agronomique (CSGA/INRA), adapted from Friel and Taylor (2001), MunozGonzález et al. (2014) and Ruth, Grossmann, Geary, and Delahunty (2001). The following materials were used: $\mathrm{NaHCO}(5.208 \mathrm{~g}), \mathrm{K}_{2} \mathrm{HPO}_{4} .3 \mathrm{H}_{2} \mathrm{O}(1.369 \mathrm{~g}), \mathrm{NaCl}(0.877 \mathrm{~g}), \mathrm{KCl}(0.477$ $\mathrm{g}), \mathrm{CaCl}_{2} .2 \mathrm{H}_{2} \mathrm{O}(0.441 \mathrm{~g}), \mathrm{NaN}_{3}(0.500 \mathrm{~g})$, bovine mucin $(2.160 \mathrm{~g})$, and porcine and 200,000 units of alpha-amylase (12 units/mg). All the products, except for alpha-amylase, were added to one liter of distilled water. The solution was agitated for $30 \mathrm{~min}$ to complete homogenization and then the alpha-amylase was added. The artificial saliva was maintained at $-20^{\circ} \mathrm{C}$ until use.

The chewing simulator parameters were defined according to previous studies (Mielle et al., 2010; Tarrega, Yven, Sémon, \& Salles, 2011; Yven, Guessasma, Chaunier, Valle, \& Salles, 2010) and, after preliminary tests, the parameters were fixed as follows: mandible and tongue forces of $30 \mathrm{daN}$; shearing force of $35 \mathrm{daN}$; shearing angle value of $1 / 8$ th tooth; 15 chewing cycles (about $50 \mathrm{~s}$ of chewing); artificial saliva flow of $2 \mathrm{~mL}$ initial and $1 \mathrm{~mL} / \mathrm{min}$ after the chewing starts; and humid air at a flow of $135 \mathrm{~mL} / \mathrm{min}$. 
Although in human consumption the whole snack may be placed in the mouth, snacks of $2 \mathrm{~cm}$ in length were weighed (to guarantee that they all had the same mass) and broken into four parts for chewing. Preliminary tests performed to determine the best snack arrangement in the chewing simulator showed the arrangement presented in Fig. 1A as the most adequate, which, after chewing, presented a food bolus similar to that of a human being (Fig. 1B). Analyses in the chewing simulator were performed in duplicate and data on the release of butyric acid was obtained from 17 to $27 \mathrm{~s}$ when the chewing simulator was used, corresponding to the period of increase in signal intensity from the start of chewing (linear

161 part of the graph - Fig. 2A).

2.3.2 Evaluation of in vitro release of butyric acid via odor

Fifty milligrams of milled snack were added to a $20-\mathrm{mL}$ hermetically sealed vial and immersed in a bath for $30 \mathrm{~min}$ at $40{ }^{\circ} \mathrm{C}$ (Conti-Silva, Bastos, \& Arêas, 2012). The vial containing the sample was inserted in the valves device and maintained for another $15 \mathrm{~min}$, also at $40^{\circ} \mathrm{C}$, for the headspace equilibrium. The valves device was activated automatically, operating as follows: for $30 \mathrm{~s}$, valves were open allowing the passage of room air through an empty vial (reference) to the PTR-ToF-MS. After that, the valves were switched, closing the connection of the reference vial to the MS at the same time as the vial containing the snack sample was connected to the MS for $180 \mathrm{~s}$. Analyses were performed in duplicate and data on the release of butyric acid was obtained from 40 to $80 \mathrm{~s}$ when the valve system was used, corresponding to the period of increase in signal intensity after the opening of the valves (linear part of the graph - Fig. 2B).

$174 \quad$ 2.3.3 Study of butyric acid release using the PTR-ToF-MS 
The study of butyric acid release from the expanded snacks was performed using an Ionicon PTR-TOF-MS 8000 detector (Ionicon Analytik, Innsbruck, Austria). The drift tube conditions used were: temperature maintained at $80^{\circ} \mathrm{C}$, operation voltage of $480 \mathrm{~V}$ and pressure of $2.3 \mathrm{mBar}$, resulting in an E/N ratio of 112 Townsends $\left(1 \mathrm{Td}=10^{-17} \mathrm{~V} . \mathrm{cm}^{2}\right)(\mathrm{E}$ : electric field strength; $\mathrm{N}$ : density). The headspace was admitted in the PTR-ToF-MS with a flow rate fixed at $100 \mathrm{~mL} / \mathrm{min}$. The scan speed was $500 \mathrm{~ms}$ for a mass range $\mathrm{m} / \mathrm{z} 0-250$. For mass calibration, the mass/charge ratios for $\mathrm{H}_{3} \mathrm{O}^{+}(\mathrm{m} / \mathrm{z} 21.022086), \mathrm{NO}^{+}(\mathrm{m} / \mathrm{z} 29.997440)$, and acetone $(\mathrm{m} / \mathrm{z}$ 59.049141) were monitored. Results were obtained evaluating the protonated butyric acid ion $\left(\mathrm{MH}^{+}\right.$ion $\mathrm{m} / \mathrm{z}$ 89.0616). As calibration curves were not produced, the data were expressed in normalized CPS (nCPS) using primary ions $\mathrm{H}_{3} \mathrm{O}^{+}$and $\mathrm{H}_{3} \mathrm{O}^{+}\left(\mathrm{H}_{2} \mathrm{O}\right)$ as recommended by the manufacturer to account for primary ion fluctuations using the PTRMS Viewer software (version 3.1.0.31). The PTR-ToF-MS was connected to the two different devices via a 1-mm internal diameter, 600-mm length, 1/16-in external diameter polyether ether ketone (PEEK) capillary (maintained at $75^{\circ} \mathrm{C}$ ).

Data from the PTR-ToF-MS, obtained through both the chewing simulator and the valve system, was analyzed from the linear part of the butyric acid release plot. During the analyses, humid air was introduced into the chewing simulator and the vials via one opened valve as the headspace was admitted in the PTR-ToF-MS with a flow rate fixed at 100 $\mathrm{mL} / \mathrm{min}$. The drift tube pressure had to be strictly constant to have stable ionization conditions, and to avoid a decreasing of the drift tube pressure (increase of the $\mathrm{E} / \mathrm{N}$ ratio parameter) due to the closing of the chewing simulator and the vials, a gas flow was needed to flush them. Thus, we analyzed only the linear part of the graph that corresponds to the headspace from the chewing simulator and the vials.

\subsection{Evaluation of the sensory profile of the expanded snacks}


The sensory profile of the snacks was evaluated through the multi-intake Temporal Dominance of Sensations (TDS) test. This study was approved by the Research Ethics Committee of the Institute of Biosciences, Literature, and Exact Sciences at São Paulo State University (Decision No. 360.800).

The test was performed in the Sensory Analysis Laboratory of the Department of Food Engineering and Technology at the same Institute, in individual booths with white light and at a temperature of approximately $22^{\circ} \mathrm{C}$, using the TimeSens ${ }^{\circledR}$ software (CSGA/INRA, Dijon, France). Nine panelists, who previously participated of an Optimized Descriptive Profile (Silva et al., 2012) of cheese-flavored snacks, were recruited for the test. Of the nine panelists, five were male, all were aged from 24 to 29 years and like little or too much of cheeseflavored snacks, and six consume this product once every 15 days or once a month. The panelists defined seven attributes in the snacks: two for texture (crunchy/crispy and hard), and five for flavor (cereal flavor, cheese flavor, oil flavor, salty taste, and umami taste). Before performing the test, the panelists were familiar with the software and were instructed that the dominant sensation is that one that captures the attention, not necessarily the most intense sensation (Pineau et al., 2009).

Multi-intake TDS analysis was conducted in triplicate for each snack, and each replicate was performed with three intakes (three units of the same snack, with $2 \mathrm{~cm}$ in length each one). In each intake of each replicate, the panelists clicked on the 'START' button on the computer screen as soon as they had the snack in the mouth. Next, they selected the attribute that attracted their attention from the list of seven attributes and only one attribute could be selected at a time. However the same attribute could be selected several times. When the 221 panelists perceived that no more sensation was dominant, they clicked on the 'STOP' button 222 to indicate the end of the TDS evaluation of this unit (intake). After this, panelists performed 
evaluation. All samples were presented in plastic cups encoded with random three-digit numbers in balanced and monadic manner and following a Williams Latin square.

\subsection{Data analysis}

2.5.1 Butyric acid in vitro release

Results from the PTR-ToF-MS tests were analyzed in two ways: first, curves showing the signal intensity against release time were fitted using a linear model and the inclination coefficient for the release of butyric acid was obtained; then, the area below this curve was calculated using the midpoint integration rule. These data were submitted to analysis of variance followed by the Tukey test, at significant level of 0.05 , using the Statistica 7.0 software (StatSoft Inc., Oklahoma, EUA).

\subsubsection{Temporal Dominance of Sensations}

TDS curves were built, standardizing the time for each intake between 0 (START) and 1 (STOP) (Galmarini, Loiseau, Debreyer, Visalli, \& Schlich, 2017; Galmarini, Visalli, \& Schlich, 2017; Galmarini, Loiseau, Visalli, \& Schlich, 2016). TDS curves show the dominance rate of each attribute over time, as well as the lines corresponding to "chance

239 level' and to 'significance level'. The 'chance level' is the dominance rate that an attribute 240 can be obtained by chance, while the 'significance level' is the minimum value of the 241 dominance rate considered as significant (Pineau et al. 2009). Therefore, an attribute is 242 considered dominant at that moment when the curve is above the significance level. However, 243 if the curve is in-between the chance and the significance level, the attribute can be considered as having a tendency towards dominance (Galmarini et al., 2017).

The TDS data was also treated in order to compare dominance durations statistically. Each intake was first time-standardized between 0 and 1 and then the 3 consecutive intakes 
were concatenated. Thus time of the 3 intakes varies between 0 and 1 for the first, 1 and 2 for the second and 2 and 3 for the third one. Dominance durations were computed from this standardized data and submitted to a two-way ANOVA model including sample, panelist and their interaction as factors, followed by Tukey test (significance level of 0.05 ). The same data was submitted to the canonical variate analysis (CVA). All analyses were performed using TimeSens ${ }^{\circledR}$ software (INRA, CSGA, Dijon, France).

\section{Results and discussion}

\subsection{In vitro release of butyric acid from the expanded snacks}

Fig. 2 shows that all snacks presented a similar release profile for butyric acid, both via aroma (Fig. 2A) and via odor (Fig. 2B). However, statistical differences were observed between the inclination coefficients of butyric acid release (Table 1) and to areas under the curve (Table 2). For butyric acid release via aroma, the control snack (without sunflower oil) presented the highest $(\mathrm{p} \leq 0.05)$ inclination coefficient (Table 1$)$, as well as the highest ( $\mathrm{p} \leq$ 0.05 ) area under the curve (Table 2), followed by the snack with $6 \mathrm{~g} / 100 \mathrm{~g}$ of sunflower oil, and then by the other snacks (12, 18 and $24 \mathrm{~g} / 100 \mathrm{~g}$ of sunflower oil). However, for butyric acid release via odor, the opposite was observed, because all snacks with sunflower oil presented higher $(\mathrm{p} \leq 0.05)$ inclination coefficients (Table 1) and areas under the curve (Table 2) in relation to the control snack.

As butyric acid was added to the corn grits before extrusion, our hypothesis is that its retention by the final product probably occurred through encapsulation inside the snack and interaction with the sunflower oil sprinkled on the product. During consumption of products without lipid, lipophilic volatile compounds, such as butyric acid, tend to be released rapidly after the food is ruptured because of mastication. In products containing lipids, the release of lipophilic volatile compounds occurs more slowly, since such compounds first need to be 
released from the food matrix (encapsulation inside the snack) and migrate through the oil interfaces (sunflower oil sprinkled on the product) to the saliva, and then released to the headspace inside the mouth (Leland, 1997; Madene, Jacquot, Scher, \& Desobry, 2006; Roos, 1997; Yuliani, Torley, \& Bhandari, 2009). This is related to the partition coefficient of the volatile compound representing the thermodynamic behavior of the compound in an organic phase and in an aqueous phase $\left(\mathrm{P}_{\mathrm{ow}}=\mathrm{C}_{\mathrm{o}} / \mathrm{C}_{\mathrm{w}}\right.$, where: $\mathrm{C}_{\mathrm{o}}$ and $\mathrm{C}_{\mathrm{w}}$, concentration of volatile compounds in the organic phase and in the water phase, respectively) (Roos, 1997; Bortnowskaa, \& Goluch, 2018). According IPCS (2018), octanol/water partition coefficient of butyric acid as $\log \mathrm{P}_{\mathrm{ow}}$ is 0.79 , showing the higher affinity of this compound by the organic phase than by the aqueous phase. Thus, in the control snack (without sunflower oil), the butyric acid was probably released quickly with the break-up of the snack structure during mastication through the chewing simulator, shown by higher inclination coefficient of release (Table 1) and area under the curve (Table 2), which corresponds to the amount of butyric acid released over the time period analyzed. In the snacks that were sprayed with sunflower oil, the release was supposedly slower, explaining the lower inclination coefficients of release and areas under the curve in relation to the control snack. Therefore, the absence of lipids, or the low quantity of lipids in the case of the snack with $6 \mathrm{~g} / 100 \mathrm{~g}$ of sunflower oil, may result in a momentary perception of butyric acid via aroma (inside the mouth), because the release is fast, different from a longer perception when the amount of lipid is higher and the release of butyric acid is slower.

In the case of butyric acid release via odor, it seems that the sunflower oil protected the snacks from the loss of butyric acid. This may have occurred due to interactions of butyric acid with lipids, requiring more time to be released due to greater resistance to mass transfer of the butyric acid in oil than in air. Moreover, this effect was independent of the amount of oil sprinkled on the snacks because the linear coefficients of release were statistically equal 
for snacks with added oil (Table 1) and the areas under the curve little discriminated between the snacks with oil (Table 2). Regarding the snacks without oil addition, we observed a lower release coefficient (Table 1) and area under the curve (Table 2), probably because during the preparation of the sample (milled), part of the butyric acid was released precisely because there was no oil to increase the mass transfer resistance and act as a protector of butyric acid.

Comparing the snacks with oil addition, the sprinkling of $6 \mathrm{~g} / 100 \mathrm{~g}$ of sunflower oil caused higher release of butyric acid via aroma and practically the same release via odor in relation to the other snacks, besides not raising the lipid content very much when compared to others. In this study, these results were complemented with the Temporal Dominance of Sensations technique providing information about the perception of the dominant sensation of the flavor of the snacks over time.

\subsection{Temporal Dominance of Sensations of the expanded snacks}

The Fig. 3 shows the TDS curves for each snack over the three intakes. For both the control snacks $(\mathrm{C} 1$ and $\mathrm{C} 2)$, a total of three attributes reached significant dominance rates over the three intakes: crunch/crispy, hard and cereal flavor. The beginning of intake was characterized by hard and crunchy/crispy followed by the cereal flavor that persisted until the end of each intake. Therefore, the absence of aroma precursors and sunflower oil (C1) and of sunflower oil (C2) allowed the dominance of the cereal flavor, coming from the extruded corn grits. Although the $\mathrm{C} 2$ snack had been produced with aroma precursors, the cheese flavor did not reach a significant dominance rate for its characterization. This is due to the importance of the lipids in releasing the volatile compounds from a food (Taylor \& Linforth, 2010; Voilley \& Etiévant, 2006), and, consequently, on the perception of flavor of the product. Although C1 had added salt and monosodium glutamate, the salty taste and umami taste did not reach a 
319 significant dominance rate for its characterization. This can also probably be explained by the influence of the lipids on the perception of non-volatile compounds (Dramane et al., 2014).

In general, the snacks with sunflower oil had significant dominance rates of all attributes. All snacks were described as crunchy/crisp, showing its importance as a dominant attribute of expanded snacks, independent of the formulation of the product. Different from the control snacks, the cheese flavor was dominant in all snacks with oil, although it was not dominant at the intake 3 of the snack with $6 \mathrm{~g} / 100 \mathrm{~g}$ oil. Snacks with oil were differentiated regarding umami and salty taste, because the umami taste had significant dominance rate for snacks with $6 \mathrm{~g} / 100 \mathrm{~g}$ and $18 \mathrm{~g} / 100 \mathrm{~g}$ oil and the salty taste for the snack with $12 \mathrm{~g} / 100 \mathrm{~g}$ oil, while both attributes described the snack with $24 \mathrm{~g} / 100 \mathrm{~g}$ oil. The snack with $12 \mathrm{~g} / 100 \mathrm{~g}$ oil was the only snack with oil that was not described by the oil flavor, although this attribute appears as dominant only at the end of the third intake for the other three snacks with oil. These results are justified in the same way as previously, due to the influence of lipids on the release of volatile compounds (Taylor \& Linforth, 2010; Voilley \& Etiévant, 2006), and on the perception of non-volatile compounds (Dramane et al., 2014). Therefore, the presence of sunflower oil aggregates dominant sensations to snacks, expanding and enriching their sensory profiles.

In the same way, the canonical variate analysis splits snacks in function of the presence or absence of oil (Fig. 4). The control snacks (C1 and C2), both without oil, were described regarding the longer duration of the attributes hard and cereal flavor, while snacks with oil were described by the longer duration of salty taste, crunchy/crisp, cheese flavor, umami taste and oil flavor. Moreover, the overlap of the ellipse of the snack with $6 \mathrm{~g} / 100 \mathrm{~g}$ of sunflower

341 oil and the ellipses of the other snack (12, 18 and $24 \mathrm{~g} / 100 \mathrm{~g})$ indicates similarity in the 342 duration of the dominant attributes of these products. Indeed, when the duration of the 343 dominant sensations are compared statistically, the snack with $6 \mathrm{~g} / 100 \mathrm{~g}$ of oil was 
344 statistically equal to the others with oil (Table 3). Therefore, the low use of sunflower oil does not alter the dominant sensations of the snacks.

\section{Conclusions}

The monitoring of in vitro release of butyric acid showed that the snack sprinkled with 6 $\mathrm{g} / 100 \mathrm{~g}$ of sunflower oil conferred a higher release of butyric acid via aroma and practically the same release via odor in relation to the other snacks. Moreover, all snacks with sunflower oil were described by the duration of salty taste, crunchy/crisp, cheese flavor, umami taste and oil flavor, indicating that the low use of sunflower oil $(6 \mathrm{~g} / 100 \mathrm{~g})$ did not alter or prejudice the dominant sensations of the snacks. The production of snacks with low addition of lipids is feasible and more studies about reducing the lipid content could be conducted in order to further increase the nutritive value of this product. It must be emphasized that lipids are macronutrients and lipophilic vitamin carriers, and so they are fundamental to human health. Therefore, along with the improvement of the nutritive value of snacks by lipid reduction, the population must be educated about the benefits of lipids to health, preventing health problems through their elimination from the diet.

\section{Acknowledgements}

The authors are grateful for financial support from the São Paulo Research Foundation (FAPESP, grant numbers 2013/00944-9 and 2016/08519-3)

\section{References}


Bhandari, B., D’Arcy, B., \& Young, G. (2001). Flavour retention during high temperature short time extrusion cooking process: A review. International Journal of Food Science and Technology, 36, 453-461.

Bortnowskaa, G., \& Goluchb, Z. (2018). Retention and release kinetics of aroma compounds from white sauces made with native waxy maize and potato starches: Effects of storage time and composition. Food Hydrocolloids, 85, 51-60.

Conti-Silva, A. C., Bastos, D. H. M., \& Arêas, J. A. G. (2012). The effects of extrusion conditions and the addition of volatile compounds and flavour enhancers to corn grits on the retention of the volatile compounds and texture of the extrudates. International Journal of Food Science and Technology, 47, 1896-1902.

Dramane, G., Akpona, S., Besnard, P., \& Khan, N. A. (2014). Cell mechanisms of gustatory lipids perception and modulation of the dietary fat preference. Biochimie, 107(Part A), 11-14.

Friel, E. N., \& Taylor, A. J. (2001). Effect of salivary components on volatile partitioning from solutions. Journal of Agricultural and Food Chemistry, 49, 3898-3905.

Galmarini, M. V., Loiseau, A., Debreyer, D., Visalli, M., \& Schlich, P. (2017). Use of multiintake Temporal Dominance of Sensations (TDS) to evaluate the influence of wine on cheese perception. Journal of Food Science, 82, 2669-2678.

Galmarini, M. V, Loiseau, A., Visalli, M., \& Schlich, P. (2016). Use of multi-intake Temporal Dominance of Sensations (TDS) to evaluate the influence of cheese on wine perception. Journal of Food Science, 81, 2566-2577. 
Galmarini, M. V, Visalli, M., \& Schlich, P. (2017). Advances in representation and analysis of mono and multi-intake Temporal Dominance of Sensations data. Food Quality and Preference, 56, 247-255.

Gaonkar, A. G., \& McPherson, A. (2006). Ingredient interactions: effects on food quality (2 ed). Boca Raton: Taylor \& Francis.

International Programme on Chemical Safety - IPCS. (2018). Butyric acid. http://www.inchem.org/documents/icsc/icsc/eics1334.htm Accessed 03 December 2018.

Lawless, H. T., \& Heymann, H. (2010). Sensory evaluation of food: principles and practices (2 ed). New York: Springer.

Leland, J. V. (1997). Flavor interactions: The greater whole. Overview Outstanding Symposia in Food Science \& Technology, 51, 75-80.

Madene, A., Jacquot, M., Scher, J., \& Desobry, S. (2006). Flavour encapsulation and controlled release - A review. International Journal of Food Science and Technology, 41, $1-21$.

Martínez-Cuesta, M. D. C., Peláez, C., \& Requena, T. (2013). Methionine metabolism: Major pathways and enzymes involved and strategies for control and diversification of volatile sulfur compounds in cheese. Critical Reviews in Food Science and Nutrition, 53, 366385.

Maskan, M., \& Altan, A. (2012). Advances in food extrusion technology. Boca Rotan: CRC Press. 
Menis, M. E. C., Milani, T. M. G., Jordano, A., Boscolo, M., \& Conti-Silva, A. C. (2013). Extrusion of flavored corn grits: Structural characteristics, volatile compounds retention and sensory acceptability. LWT - Food Science and Technology, 54, 434-439.

Mielle, P., Tarrega, A., Sémon, E., Maratray, J., Gorria, P., Liodenot, J. J., et al. (2010). From human to artificial mouth, from basics to results. Sensors and Actuators, B: Chemical, $146,440-445$.

Munoz-González, C., Feron, G., Guichard, E., Rodr, J. J., Mart, P. J., Moreno-Arribas, M. V., \& Pozo-bayo, M. A. (2014). Understanding the role of saliva in aroma release from wine by using static and dynamic headspace conditions. Journal of Agricultural and Food Chemistry, 62, 8274-8288.

Pineau, N., Schlich, P., Cordelle, S., Mathonnière, C., Issanchou, S., Imbert, A., et al. (2009). Temporal Dominance of Sensations: Construction of the TDS curves and comparison with time-intensity. Food Quality and Preference, 20, 450-455.

Reineccius, G. (2006). Flavor chemistry and technology. Boca Raton: Taylor \& Francis Group, LLC.

Roos, K. B. (1997). How lipids influence food flavor. Overview Outstanding Symposia in Food Science \& Technology, 51, 60-61.

Ruth, S. M. Van, Grossmann, I., Geary, M., \& Delahunty, C. M. (2001). Interactions between artificial saliva and 20 aroma compounds in water and oil model systems. Journal of Agricultural and Food Chemistry, 49, 2409-2413. 
425 Salles, C., Mielle, P., Quéré, J. L. Le, Renaud, R., Maratray, J., Maratray, J., Gorria, P., Liaboeuf, J. and Liodenot, J.-J. (2006). A novel prototype to closely mimic mastication for in vitro dynamic measurements of flavour release. In W. L. P. Bredie \& M. A. Petersen (Eds.), Flavour science: recent advances and trends (pp. 581-584). Amsterdam: Elsevier.

Salles, C., Tarrega, A., Mielle, P., Maratray, J., \& Gorria, P. (2007). Development of a chewing simulator for food breakdown and the analysis of in vitro flavor compound release in a mouth environment. Journal of Food Engineering, 82, 189-198.

Silva, R. C. S. N., Minim, V. P. R., Simiqueli, A. A., Moraes, L. E. S., Gomide, A. I., \& Minim, L. A. (2012). Optimized Descriptive Profile: A rapid methodology for sensory description. Food Quality and Preference, 24, 190-200.

Tabela Brasileira de Composição de Alimentos (TBCA) (2018). Universidade de São Paulo (USP). Food Research Center (FoRC). Versão 6.0. São Paulo, 2017. http://www.fcf.usp.br/tbca/ Accessed 12 December 2018.

Tarrega, A., Yven, C., Sémon, E., \& Salles, C. (2011). In-mouth aroma compound release during cheese consumption: Relationship with food bolus formation. International Dairy Journal, 21, 358-364. Publishing Ltd.

LLC. 
446 Yuliani, S., Torley, P. J., Arcy, B. D. Õ., Nicholson, T., \& Bhandari, B. (2006). Extrusion of

447 mixtures of starch and D-limonene encapsulated with $\beta$-cyclodextrin: Flavour retention

$448 \quad$ and physical properties. Food Research International, 39, 318-331.

449 Yuliani, S., Torley, P. J., \& Bhandari, B. (2009). Physical and processing characteristics of 450 extrudates made from starch and d-limonene mixtures. International Journal of Food

$451 \quad$ Properties, $12,482-495$.

452 Yven, C., Guessasma, S., Chaunier, L., Valle, G. Della, \& Salles, C. (2010). The role of 453 mechanical properties of brittle airy foods on the masticatory performance. Journal of $454 \quad$ Food Engineering, 101, 85-91. 
456 Fig. 1. Distribution of the snack in the chewing simulator before (A) and after chewing (B).

457 Fig. 2. Profile of release of butyric acid from the expanded snacks via aroma (A) and via odor

458 (B). Legend: $\mathrm{C} 2$ - Control 2 (with addition of aroma precursors and without sunflower oil); $6 \mathrm{~g} / 100 \mathrm{~g}$ - snack

459 with $6 \mathrm{~g} / 100 \mathrm{~g}$ of sunflower oil; $12 \mathrm{~g} / 100 \mathrm{~g}$ - snack with $12 \mathrm{~g} / 100 \mathrm{~g}$ of sunflower oil; $18 \mathrm{~g} / 100 \mathrm{~g}$ - snack with 18

$460 \mathrm{~g} / 100 \mathrm{~g}$ of sunflower oil; $24 \mathrm{~g} / 100 \mathrm{~g}$ - snack with $24 \mathrm{~g} / 100 \mathrm{~g}$ of sunflower oil.

461 Fig. 3. Multi-intake TDS curves for the expanded snacks. Legend: Cl - Control 1 (snack with salt 462 and monosodium glutamate, but without aroma precursors and sunflower oil); C2 - Control 2 (with addition of 463 aroma precursors and without sunflower oil); $6 \mathrm{~g} / 100 \mathrm{~g}$ - snack with $6 \mathrm{~g} / 100 \mathrm{~g}$ of sunflower oil; $12 \mathrm{~g} / 100 \mathrm{~g}$ 464 snack with $12 \mathrm{~g} / 100 \mathrm{~g}$ of sunflower oil; $18 \mathrm{~g} / 100 \mathrm{~g}$ - snack with $18 \mathrm{~g} / 100 \mathrm{~g}$ of sunflower oil; $24 \mathrm{~g} / 100 \mathrm{~g}$ - snack 465 with $24 \mathrm{~g} / 100 \mathrm{~g}$ of sunflower oil. The $\mathrm{x}$-axes represent the standardized time between 0 and 1.

466 Fig. 4. Canonical Variate Analysis for the duration of dominant attributes for the expanded 467 snacks. Legend: $\mathrm{C} 1$ - Control 1 (snack with salt and monosodium glutamate, but without aroma precursors and 468 sunflower oil); $\mathrm{C} 2$ - Control 2 (with addition of aroma precursors and without sunflower oil); $6 \mathrm{~g} / 100 \mathrm{~g}$ - snack 469 with $6 \mathrm{~g} / 100 \mathrm{~g}$ of sunflower oil; $12 \mathrm{~g} / 100 \mathrm{~g}$ - snack with $12 \mathrm{~g} / 100 \mathrm{~g}$ of sunflower oil; $18 \mathrm{~g} / 100 \mathrm{~g}$ - snack with 18 $470 \mathrm{~g} / 100 \mathrm{~g}$ of sunflower oil; $24 \mathrm{~g} / 100 \mathrm{~g}$ - snack with $24 \mathrm{~g} / 100 \mathrm{~g}$ of sunflower oil. 


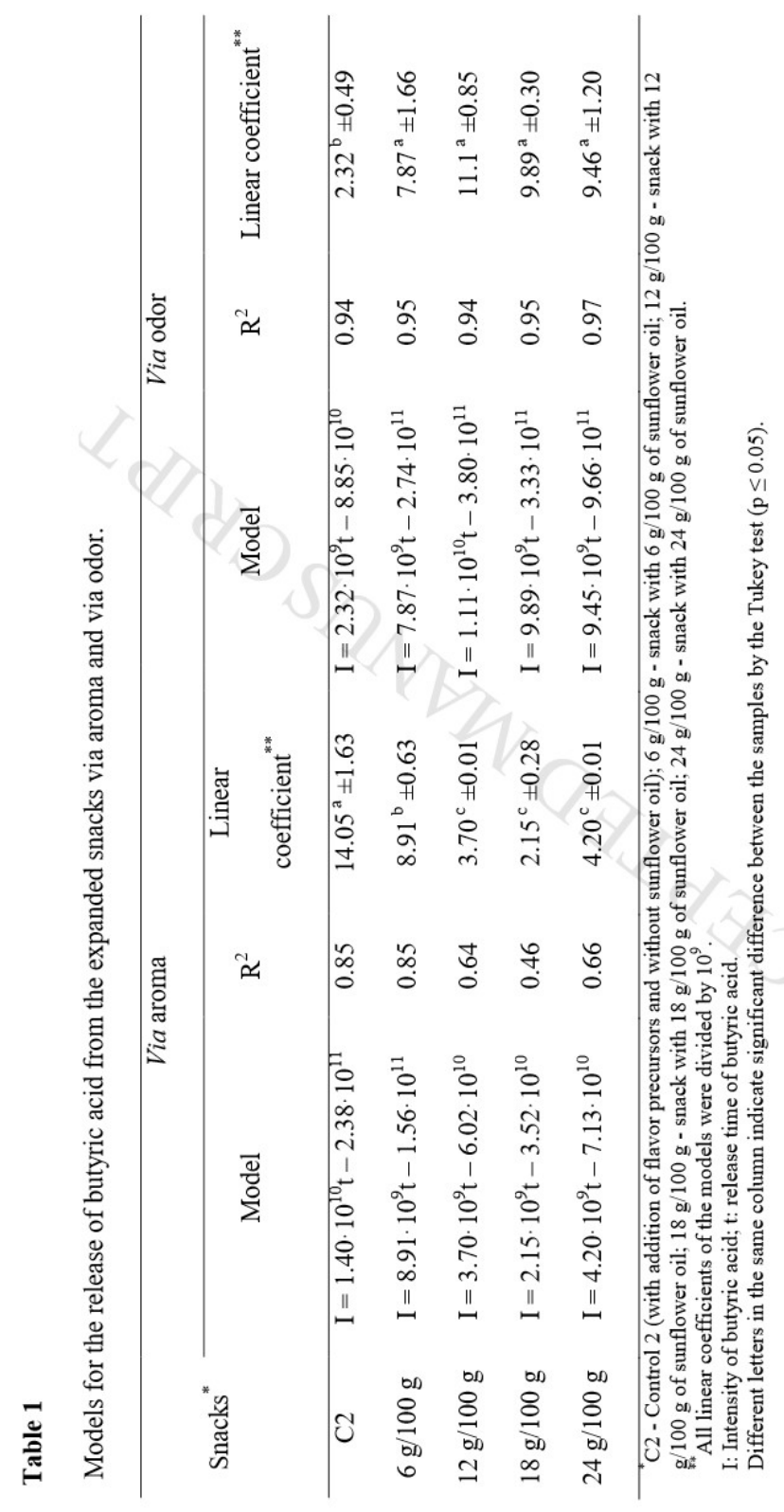




\section{Table 2}

Area under the curve of release of butyric acid from the expanded snacks via aroma and odor.

\begin{tabular}{ccc}
\hline Snacks $^{*}$ & Via aroma $^{* *}$ & Via odor \\
\hline $\mathrm{C} 2$ & $32.6^{\mathrm{a}} \pm 3.57$ & $1.78^{\mathrm{c}} \pm 0.27$ \\
$6 \mathrm{~g} / 100 \mathrm{~g}$ & $25.3^{\mathrm{b}} \pm 0.76$ & $4.64^{\mathrm{b}} \pm 0.79$ \\
$12 \mathrm{~g} / 100 \mathrm{~g}$ & $9.08^{\mathrm{c}} \pm 0.57$ & $6.53^{\mathrm{a}} \pm 0.21$ \\
$18 \mathrm{~g} / 100 \mathrm{~g}$ & $7.03^{\mathrm{c}} \pm 0.32$ & $5.87^{\mathrm{ab} \pm 0.26}$ \\
$24 \mathrm{~g} / 100 \mathrm{~g}$ & $7.57^{\mathrm{c}} \pm 0.03$ & $6.06^{\mathrm{ab} \pm 0.56}$
\end{tabular}

$\mathrm{C} 2$ - Control 2 (with addition of flavor precursors and without sunflower oil); $6 \mathrm{~g} / 100 \mathrm{~g}$ - snack with $6 \mathrm{~g} / 100$ $\mathrm{g}$ of sunflower oil; $12 \mathrm{~g} / 100 \mathrm{~g}$ - snack with $12 \mathrm{~g} / 100 \mathrm{~g}$ of sunflower oil; $18 \mathrm{~g} / 100 \mathrm{~g}$ - snack with $18 \mathrm{~g} / 100 \mathrm{~g}$ of sunflower oil; $24 \mathrm{~g} / 100 \mathrm{~g}$ - snack with $24 \mathrm{~g} / 100 \mathrm{~g}$ of sunflower oil.

${ }_{* * *}^{* *}$ Values of area (arbitrary units) were divided by $10^{9}$

Values of area (arbitrary units) were divided by $10^{13}$

Different letters in the same column indicate a significant difference between the samples by the Tukey test (p $\leq 0.05)$. 


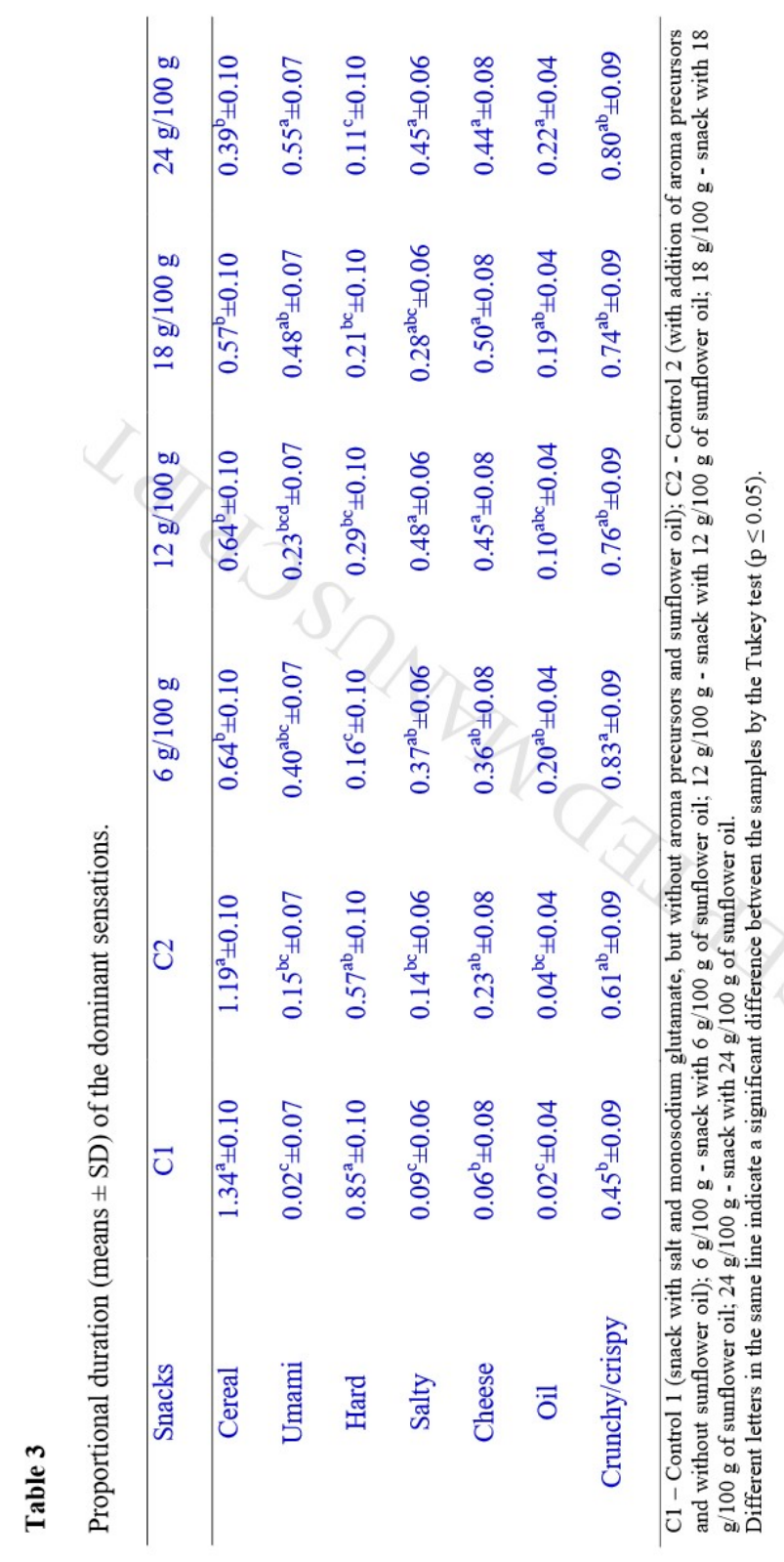




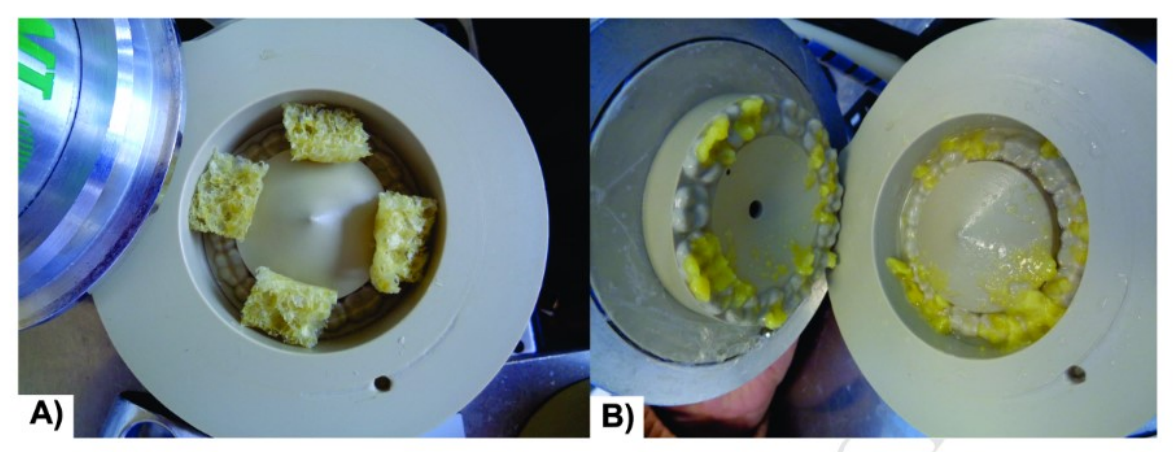




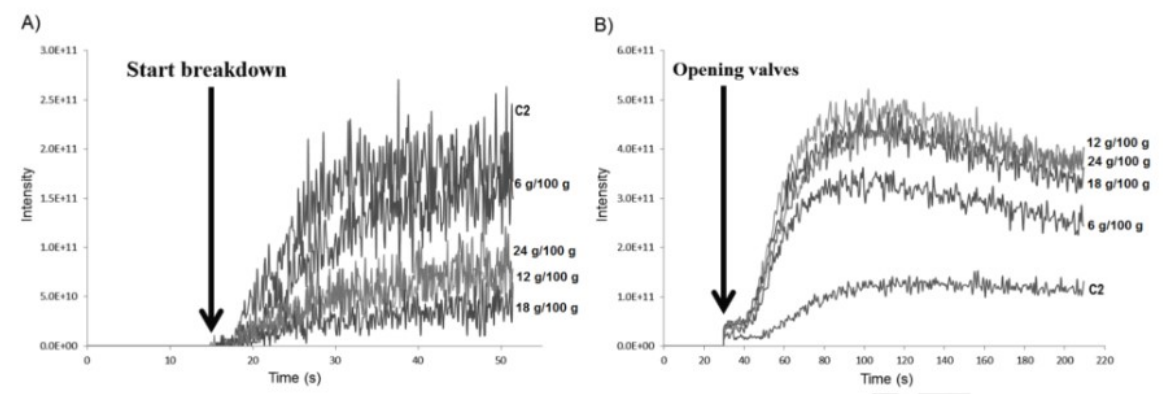



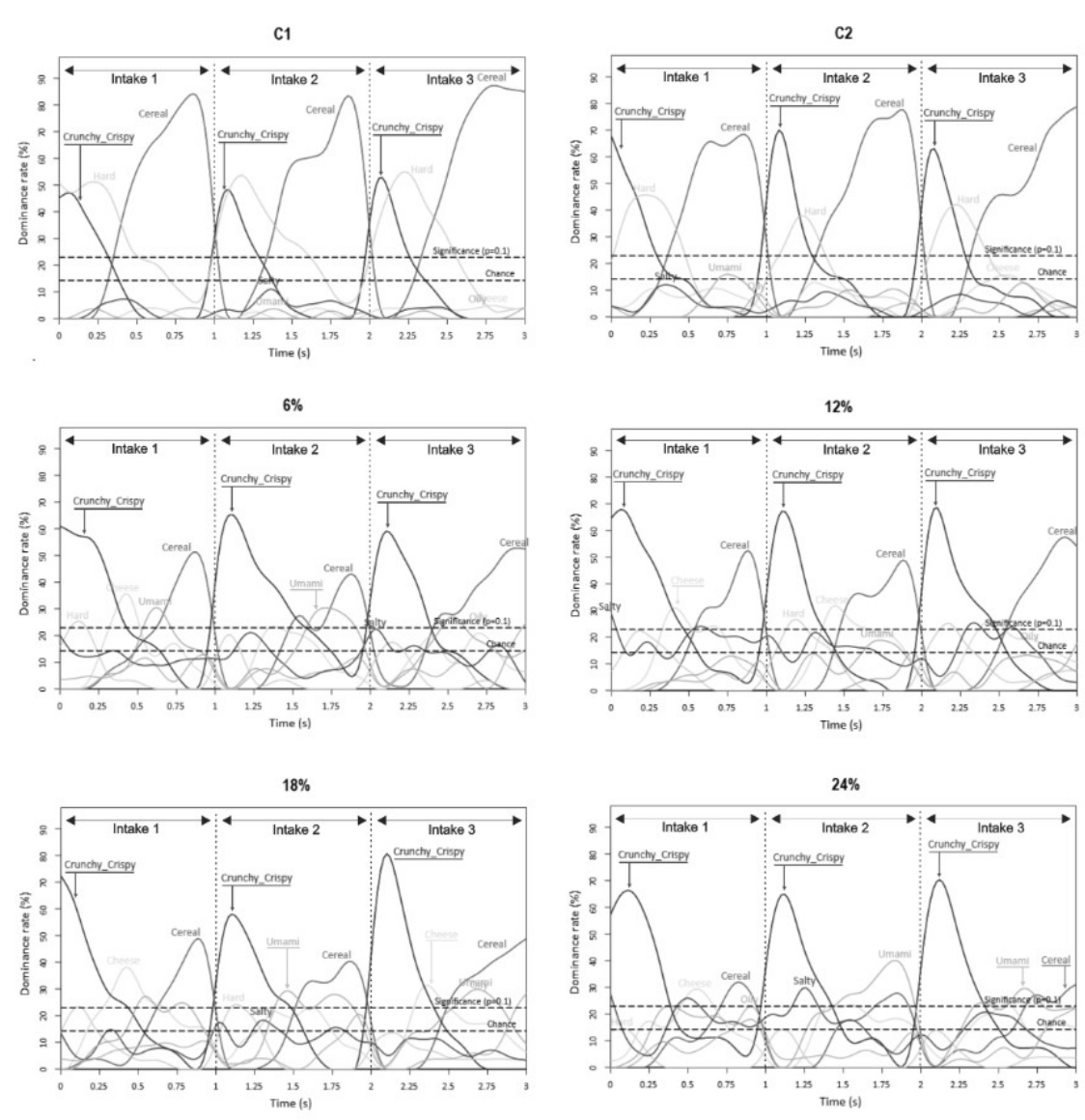


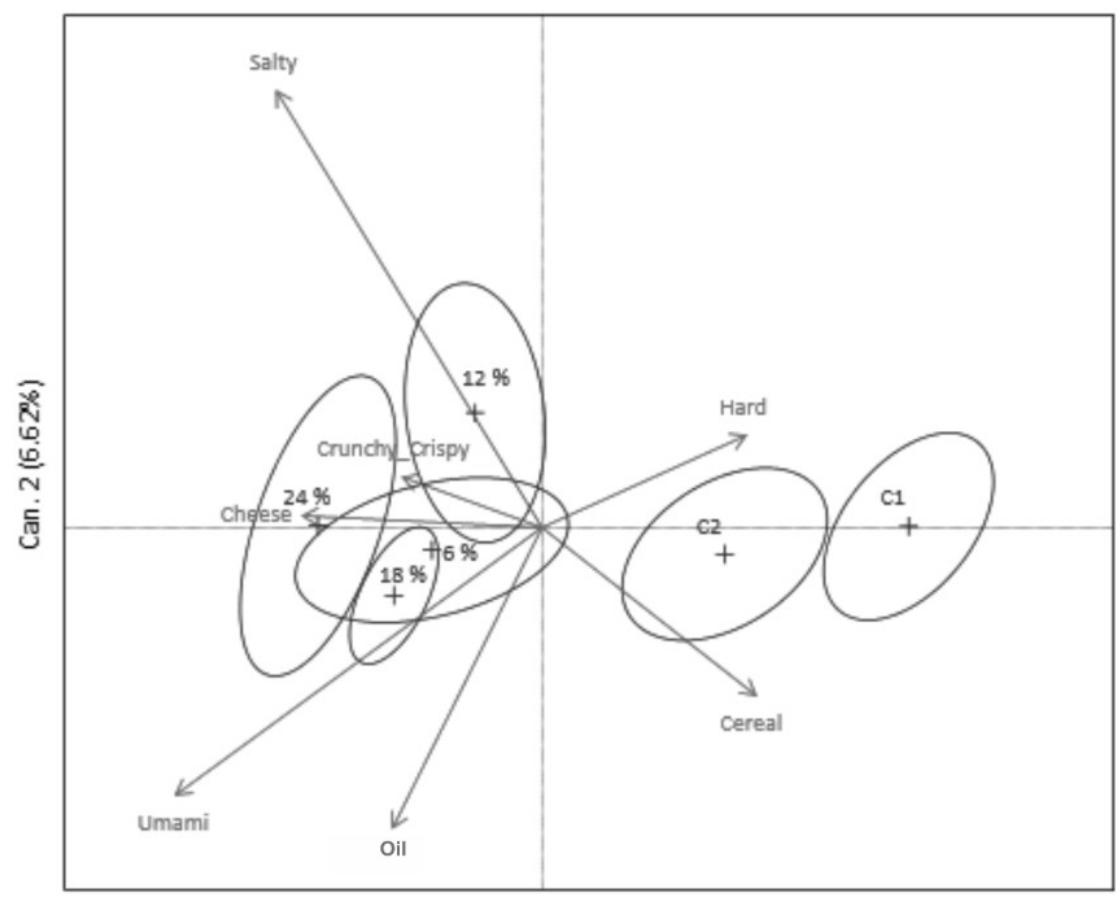

Can. 1 (89.62\%)

NDIMSIG=1, F=5.931 $(p<0.001)$

Confidence ellipses $=90 \%$ 
Highlights

- Butyric acid and cysteine were used as aroma precursors in expanded snacks.

- The lower use of oil (6\%) conferred better release of butyric acid measured in vitro.

- All snacks with oil $(6,12,18$ or $24 \%)$ were described by the same dominant sensations.

- Aroma precursors are an alternative for producing snacks with low lipid content. 